ISSN 0206-5657. Вісник Львівського університету. Серія біологічна. 2018. Випуск 78. С. 45-50 Visnyk of the Lviv University. Series Biology. 2018. Issue 78. P. 45-50

\title{
THE ROLE OF HERBARIUM OF THE OJCÓW NATIONAL PARK (SOUTHERN POLAND) IN STUDIES ON THE DIVERSITY OF LOCAL FLORAS
}

\author{
A. Soltys-Lelek ${ }^{1}$, K. Możdżeń ${ }^{2}$, B. Barabasz-Krasny ${ }^{2}$, I. Turisová ${ }^{3}$, P. Turis ${ }^{4}$ \\ ${ }^{1}$ Ojców National Park, 32-047 Ojców 9, Poland \\ e-mail:ana_soltys@wp.pl \\ ${ }_{2}^{2}$ Institute of Biology, Pedagogical University in Cracow \\ 2, Podchorażych St., Kraków 30-084, Poland \\ e-mail: kasiamozdzen@interia.pl,beata_barabasz@poczta.onet.pl \\ ${ }^{3}$ Faculty of Natural Sciences, Matej Bel University \\ 40, Tajovského St., Banská Bystrica 974 01, Slovakia \\ e-mail: Ingrid.Turisova@umb.sk \\ ${ }^{4}$ Low Tatras National Park, 10 Lazovná St., Banská Bystrica 974 01, Slovakia \\ e-mail:peter.turis@sopsr.sk
}

\begin{abstract}
This study concerns the role of small herbaria in studies of the local flora diversity, on the example of the herbarium of the Ojców National Park (ONP). This herbarium was established in the 1980s. It was initially only a floristic documentation for the park, but over time it have became a place for collecting the floristic material from various regions of Poland and other countries. The herbarium currently holds over 6600 herbarium sheets, of which the collections of critical taxa of the genera Rosa, Crataegus, and Rubus are particularly valuable.
\end{abstract}

Keywords: floristic studies, herbarium collection, Ojców National Park, Poland

The herbaria played and still play an important role in taxonomic and floristic research. They are the basic form of collecting scientific documentation in the botanic studies and, more recently, an important source of DNA for molecular taxonomic research. Old herbaria are of great scientific importance because they provide knowledge about changes of plants ranges, historical nomenclature, diversity of local floras, etc. The dried herbarium specimens can provide almost as much basic anatomical and morphological data as live plants, and they can also be used for various types of the chemical analyzes [1].

The herbarium in the Ojców National Park (acronym OPN) was initiated in the 1980s by the then employee of the park, MSc. Andrzej W. Biderman. At that time, it fulfilled a documentary function only for the floristic collections from the Ojców National Park. However, over time, it became a place for collecting the botanical material from other areas of Poland, and even from other countries [3]. Since 2001 until now, scientific supervision of the herbarium is the responsibility of the staff botanist of the park, Dr. Anna Soltys-Lelek, specializing in critical species of the genera Rubus, Rosa, and Crataegus.

The aim of this contribution is to present the role of small herbaria in studies on patterns of diversity of the local flora on the example of a herbarium functioning in the Ojców National Park (ONP).

\section{Material}

All data on the collections deposited in the ONP herbarium was obtained through direct analysis of the herbarium sheets/specimens (fig. 1) and the herbarium database. On this basis, compilations were made, illustrating the scope of floristic studies in which ONP employees participated individually or in cooperation with various scientific units. These comparisons relate to, e.g., the number of taxa (of the family, genus, and species ranks) within various groups of

(C) Sołtys-Lelek A., Możdżeń K., B. Barabasz-Krasny et al., 2018 
А. Солтис-Лелек, К. Можджень, Б. Барабаш-Красни та ін. ISSN 0206-5657. Вісник Львівського університету. Серія біологічна. 2018. Випуск 78

plants (cryptogamic plants, vascular plants, genera Crataegus, Rosa, and Rubus), which were documented in the ONP herbarium, the total number of sheets in the herbarium, or the number of sheets of representatives of various taxonomic groups, collected in various regions of Poland and other countries.

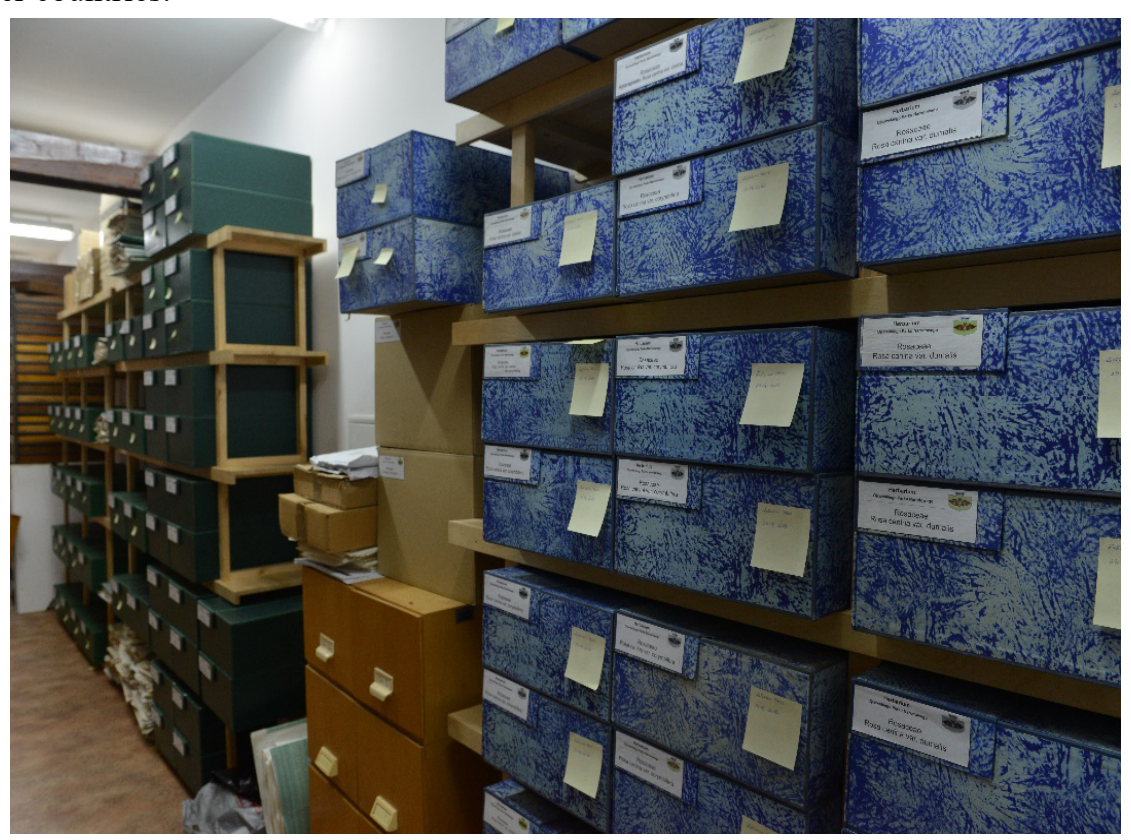

Fig. 1. The method of storing herbarium specimens in the herbarium of the Ojców National Park (Photo R. Cieślik, archiwum OPN)

\section{Results and discussion}

At present, the herbarium of ONP counts over 6600 sheets, of which the most (about 3,000) include taxa of the genus Rosa (Fig. 2).

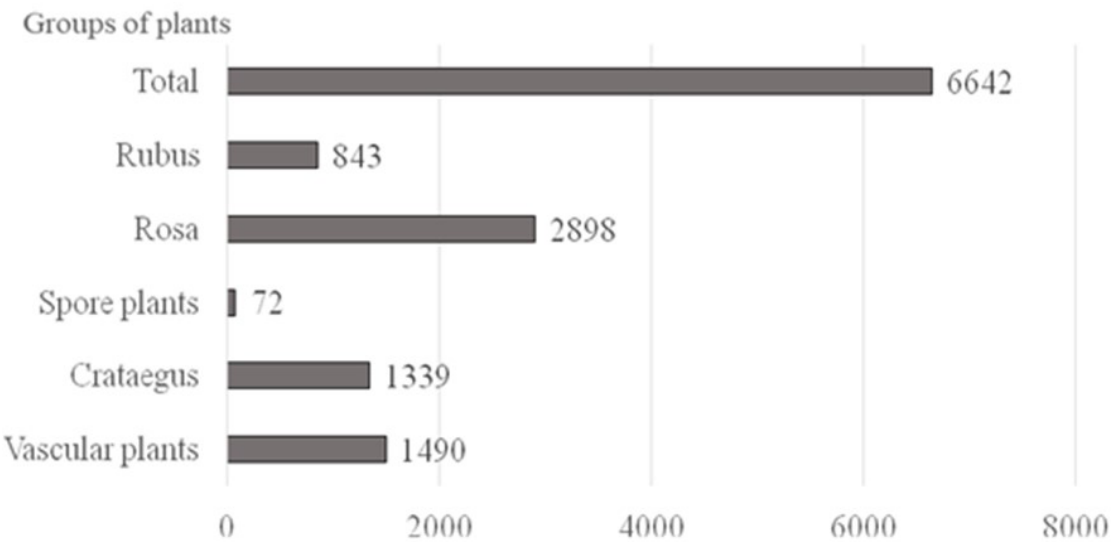

Fig. 2. Comparison of the number of herbarium sheets from various groups of plants in the herbarium of Ojców National Park (Tab. 1).

In total, about 600 species from nearly 300 genera and over 70 families are deposited here 
Comparison of the number of taxa within various groups of plants found in the materials of the herbarium of the Ojców National Park

\begin{tabular}{|l|l|l|l|l|l|l|}
\hline $\begin{array}{c}\text { Groups of plants } \\
\text { Taxons }\end{array}$ & $\begin{array}{c}\text { Cryptogamic } \\
\text { plants }\end{array}$ & Vascular plants & Genus Crataegus & Genus Rosa & Genus Rubus & Total \\
\hline Family & 6 & 71 & 0 & 0 & 0 & 77 \\
Genera & 10 & 274 & 1 & 1 & 1 & 287 \\
Species & 18 & 506 & 12 & 24 & 26 & 586 \\
\hline
\end{tabular}

Most plants in the herbarium ONP database come from the Krakowsko-Częstochowska Upland (2660 sheets), Ojców National Park (1476 sheets), and national parks of Slovakia (920 sheets) and Ukraine (853); see Table 2.

Table 2

Comparison the number of herbarium sheets from various groups of plants collected in different regions of Poland and other countries, occurring in the herbarium materials of the Ojców National Park; Abbreviations: NP - National Park, Mts - Mountains

\begin{tabular}{|c|c|c|c|c|c|c|}
\hline \multirow[b]{2}{*}{ Region } & \multicolumn{5}{|c|}{ Groups of plants } & \multirow[b]{2}{*}{ Total } \\
\hline & $\begin{array}{l}\text { Cryptogamic } \\
\text { plants }\end{array}$ & $\begin{array}{l}\text { Vascular } \\
\text { plants }\end{array}$ & $\begin{array}{c}\text { Genus } \\
\text { Crataegus }\end{array}$ & $\begin{array}{c}\text { Genus } \\
\text { Rosa }\end{array}$ & $\begin{array}{l}\text { Genus } \\
\text { Rubus }\end{array}$ & \\
\hline \multicolumn{7}{|l|}{ Poland } \\
\hline Beskidy Mts & & 3 & & 2 & & 5 \\
\hline Biebrza Basin & & 1 & & & & 1 \\
\hline Bielska Plain & & & 1 & & & 1 \\
\hline Gorczański NP & & & & & 37 & 37 \\
\hline Gorzów Basin & & & & 3 & & 3 \\
\hline Karkonoski NP & & 2 & & & & 2 \\
\hline Kielecko-Sandomierska Upland & & 3 & 43 & 10 & 1 & 57 \\
\hline Krakowsko-Częstochowska Upland & 2 & 374 & 417 & 1288 & 579 & 2660 \\
\hline Masovian Plain & & & 1 & & & 1 \\
\hline Miechowska Upland & & 1 & 28 & 40 & & 69 \\
\hline Nowotarg Basin & & & & 1 & & 1 \\
\hline Nidziańska Basin & & 26 & 126 & 346 & & 498 \\
\hline Ojców NP & 69 & 1037 & 56 & 89 & 225 & 1476 \\
\hline Pieniny Mts & & 7 & & & & 7 \\
\hline Podgrodzie & & 4 & & & & 4 \\
\hline Pojezierze & & & & 1 & & 1 \\
\hline Puszcza Białowieska & & 1 & & & & 1 \\
\hline Puszcza Niepołomicka & & & 1 & & & 1 \\
\hline Roztoczański NP & & 1 & & & & 1 \\
\hline Rybnicki Plateau & & 0 & 4 & 1 & & 5 \\
\hline Śląska Upland & & & & 3 & & 3 \\
\hline Świętokrzyskie Mts & & 13 & & & & 13 \\
\hline Tatrzański NP & 1 & 8 & & 1 & & 10 \\
\hline Ujście Warty NP & & & 1 & & & 1 \\
\hline Western Sudetes & & 1 & & & & 1 \\
\hline Wielkopolska & & 2 & & & & 2 \\
\hline \multicolumn{7}{|l|}{ Other countries } \\
\hline Lithuanian Lake District /Lithuania & & & 2 & 3 & & 5 \\
\hline Lower Tatra NP/Slovakia & & & 358 & 562 & & 920 \\
\hline Mallorca /Spain & & & 1 & & & 1 \\
\hline North Tunisia & & 1 & & & & 1 \\
\hline Western Ukraine & & 5 & 300 & 547 & 1 & 853 \\
\hline Northern Hungary & & & & 1 & & 1 \\
\hline
\end{tabular}


А. Солтис-Лелек, К. Можджень, Б. Барабаш-Красни та ін. ISSN 0206-5657. Вісник Львівського університету. Серія біологічна. 2018. Випуск 78

Based on the ONP collections from the Krakowsko-Częstochowska Upland and ONP, publications documenting the local flora were prepared and published [e.g. 2, 4-7, 9, 21]. The materials deposited here became the basis for studies of regional floras, especially taxa of the taxonomically critical genera Rosa, Crataegus, and Rubus. These studies concern both various regions of Poland [e.g. 12, 24] and other countries, in particular: Low Tatras National Park in Slovakia [10, 12-14, 16-20, 22], Roztochya Biosphere Reserve [15], Medobory Nature Reserve $[8,11]$, and Podilskyi Tovtry National Nature Park [23] in Ukraine.

The herbarium of ONP is constantly growing. Approximately 100 new sheets are added annually. The function of this herbarium is not only documentation, but also the conservation of the material for research on the variability of species, which is especially important in the case of critical species of Rosa, Crataegus, and Rubus [10, 14, 17]. Certainly, the ONP herbarium also has didactic and educational functions. Herbarium specimens can be inspirational for young students of science; for example, they can teach students of universities and primary schools to identify species, and provide a model for collecting their own herbaria, etc.

In the case of the ONP herbarium, the weakness in the functioning is the lack of a website. That blocks the access to our database for a wider range of potential users. An electronic database may be used only on the spot, or it is possible to browse the herbarium sheets directly.

\section{Conclusion}

In the era of considerable anthropogenic transformations, the herbarium is the only place where you can see plants that are no longer found in old localities, and to get information about their former habitats. This is important for conservation of endangered and threatened taxa and their reintroduction and restitution, especially in protected areas, such as national parks. Because of that, small herbaria, such as the herbarium of the Ojców National Park, play an important role in maintaining the local floristic diversity.

\section{REFERENCES}

1. Drobnik J. Zielnik i zielnikoznawstwo. Warszawa: Wydawnictwo Naukowe PWN, 2007. 294 pp.

2. Michalik S., Bąba W. Sorbus intermedia L. - nowy gatunek we florze Ojcowskiego Parku Narodowego // Fragm. Flor. Geobot. Polonica. 1999. T. 4. P. 192-195.

3. Partyka J. Muzeum Ojcowskiego Parku Narodowego - tradycje, wystawy, zbiory. [In:] D. J. Gwiazdowicz (ed.) Muzealnictwo Przyrodnicze w Polsce. Gołuchów: Ośrodek Kultury Leśnej w Gołuchowie. 2017. P. 169-186.

4. Soltys A., Popek R., Barabasz-Krasny B. Róże Ojcowskiego Parku Narodowego. [In:] J. Partyka (ed.) Zróżnicowanie i przemiany środowiska przyrodniczo-kulturowego Wyżyny Krakowsko-Częstochowskiej. Przyroda. Ojców: Wyd. Ojcowski Park Narodowy, 2004. T. I. P. 191-194.

5. Soltys A. Nowe taksony krytycznych rodzajów Crataegus i Rubus (Rosaceae) we florze Wyżyny Krakowsko-Częstochowskiej // Fragm. Flor. Geobot. Polonica. 2005. Vol. 12. № 2. P. 409-412.

6. Soltys A., Popek R. Rosa woodsii (Rosaceae) - nowy gatunek we florze Wyżyny KrakowskoCzęstochowskiej // Fragm. Flor. Geobot. Polonica. 2007. Vol. 14. № 1. P. 195-212.

7. Soltys-Lelek A. Rodzaj Crataegus L. w Ojcowskim Parku Narodowym // Prądnik. Prace Muz. Szafera. 2008. T. 18. P. 7-36.

8. Soltys-Lelek A. Wild roses of the Medobory Nature Reserve and its protection zone (Podolian Hills, Western Ukraine) // Visnyk Lviv Univ. Ser. Biol. 2011. T. 56. P. 65-83. 
А. Солтис-Лелек, К. Можджень, Б. Барабаш-Красни та ін.

9. Sottys-Lelek A. Chorologia krytycznych rodzajów - Crataegus L., Rosa L., Rubus L. na Wyżynie Krakowsko-Częstochowskiej // Prądnik. Prace Muz. Szafera. 2011. T. 21. P. 5-109.

10. Soltys-Lelek A., Barabasz-Krasny B. Turis P., Turisová I. Taxonomic revision of roses (Rosa sp.) of selected areas in buffer zone of the National Park Low Tatras (Slovakia) // Modern Phytomorphology. 2012. T. 1. P. 11-14.

11. Soltys-Lelek A. Genus Crataegus of the Medobory Nature Reserve and its protection zone (Podolian Hills, Western Ukraine) // Visnyk Lviv Univ. Ser. Biol. 2012. T. 59: P. 89-99.

12. Soltys-Lelek A. Crataegus and Rosa genera in the Solec Basin and southern part of the Pińczów Hummock (Southern Poland) // Biodiv. Res. Concerv. 2012. Vol. 25. № 1. P. 55-66.

13. Sołtys-Lelek A., Barabasz-Krasny B., Turis P., Turisová I. Chorológia niektorých taxónov kritických rodov Crataegus L. a Rosa L. vo vybraných častiach Národného parku Nízke Tatry. Čast' 1 // Naturae Tutela. 2012. Vol. 16. № 2. P. 125-140.

14. Soltys-Lelek A., Barabasz-Krasny B., Turis P., Turisová I. The genus Crataegus L. in the western part of the buffer zone of the Low Tatras National Park (Slovakia), in accordance with recent morphological and systematic recognition // Modern Phytomorphology. 2013. T. 3. P. 19-24.

15. Soltys-Lelek A., Barabasz-Krasny B. 2013. Genera Crataegus L. and Rosa L. of the Biosphere Reserve "Roztochya" and adjacent areas (Roztochya (Roztocze) Hills, Western Ukraine) // Visnyk Lviv University. Ser. Biol. 2013. T. 63. P. 86-97.

16. Soltys-Lelek A., Barabasz-Krasny B., Turis P., Turisová I. Chorológia niektorých taxónov kritických rodov Crataegus L. a Rosa L. vo vybraných častiach Národného parku Nízke Tatry. Čast' 2 // Naturae Tutela. 2013. Vol. 17. № 2. P. 125-134.

17. Soltys-Lelek A., Barabasz-Krasny B., Turis P., Turisová I. Morphological differentiation of Rosa agrestis Savi in the buffer zone of the Low Tatras National Park (Slovakia) // Modern Phytomorphology. 2014. T. 5. P. 53-61.

18. Soltys-Lelek A., Barabasz-Krasny B., Turis P., Turisová I. Chorológia niektorých taxónov kritických rodov Crataegus L. a Rosa L. vo vybraných častiach Národného parku Nízke Tatry. Čast' 3 // Naturae Tutela. 2014. Vol. 18. № 1. P. 29-38.

19. Soltys-Lelek A., Barabasz-Krasny B., Turis P., Turisová I. Rosa dumalis Bechst. in the buffer zone of the Low Tatras National Park (Slovakia) - morphological differentiation // Modern Phytomorphology. 2015. T. 7. P. 39-45.

20. Sołtys-Lelek A., Barabasz-Krasny B., Turis P., Turisová I. Chorológia niektorých taxónov kritických rodov Crataegus L. a Rosa L. vo vybraných častiach Národného parku Nízke Tatry. Čast’ 4 // Naturae Tutela. 2015. Vol. 19. № 2. P. 119-131.

21. Soltys-Lelek A., Wiśniowski B. Ambrozja bylicolistna Ambrosia artemisiifolia L. - nowe zagrożenie dla flory Ojcowskiego Parku Narodowego (Południowa Polska) // Prądnik. Prace Muz. Szafera. 2015. T. 25. P. 111-118.

22. Soltys-Lelek A., Barabasz-Krasny B., Turis P., Turisová I. Chorológia niektorých taxónov kritických rodov Crataegus L. a Rosa L. vo vybraných častiach Národného parku Nízke Tatry. Čast' 5 // Naturae Tutela. 2016. Vol. 20. № 1. P. 5-19.

23. Soltys-Lelek A., Oliiar H. The species of the genus Crataegus L. in the National Nature Park 'Podilskyi Tovtry' (Podolian Hills, Western Ukraine) // Biodiv. Res. Conserv. 2016. Vol. 44. № 1. P. 25-34.

24. Soltys-Lelek A. Gruszka W. Wild roses and hawthorns of urban area: a case study of Piła in Poland // Biodiv. Res. Conserv. 2016. Vol. 43. № 1. P. 27-40. 
А. Солтис-Лелек, К. Можджень, Б. Барабаш-Красни та ін. ISSN 0206-5657. Вісник Львівського університету. Серія біологічна. 2018. Випуск 78

\section{РОЛЬ ГЕРБАРІЮ ОЙЦОВСЬКОГО НАЦІОНАЛЬНОГО ПАРКУ (ПІВДЕННА ПОЛЬЩА) В ДОСЛІДЖЕННЯХ РІЗНОМАНІТТЯ ЛОКАЛЬНИХ ФЛОР}

\section{А. Солтис-Лелек ${ }^{1}$, К. Можджень ${ }^{2}$, Б. Барабаш-Красни ${ }^{2}$, І. Турісова ${ }^{3}$, П. Туріс ${ }^{4}$}

${ }^{1}$ Ойцовський національний парк, 32-047 Ойцฺов, 9, Польщุа e-mail:ana_soltys@wp.pl

${ }^{2}$ Інститут біологіі, Педагогічний університет вул. Подхоронжих, 2, Краків 30-084, Польща e-mail: kasiamozdzen@interia.pl,beata_barabasz@poczta.onet.pl

${ }^{3}$ Факультет природничих наук, Університет Матея Бель

вул. Тайовскего, 40, Банська Бистричя 974 01, Словаччина e-mail: Ingrid.Turisova@umb.sk

${ }^{4}$ Національний парк Низькі Татри

вул. Лазовна, 10, Банська Бистриия 974 01, Словаччина e-mail: peter.turis@sopsr.sk

Ця праця стосується висвітлення ролі малих гербаріїв у дослідженнях різноманіття локальних флор на прикладі гербарію, який діє в Ойцовському національному парку (ОНП). Цей гербарій було засновано у 80-х роках XX ст. На початках він використовувався лише в цілях флористичного обліку в парку, але з часом його колекції поповнилися зразками з інших регіонів Польщі та 3-за кордону.

На даний час гербарій ОНП налічує понад 6600 аркушів, із яких більшість (близько 3 000) становлять таксони роду Rosa. Всього тут розміщується близько 600 видів приблизно із 300 родів і понад 70 родин.

Більшість рослин у гербарній базі ОНП походять із Краківсько-Ченстоховської височини (2 660 аркушів), Ойцовського національного парку (1 476 аркушів) і національних парків Словаччини (920 аркушів) та України (853). Базуючись на зборах ОНП з Краківсько-Ченстоховської височини та ОНП, було опубліковано праці, в яких документується місцева флора. Матеріали, які зберігаються в гербарії, послугували основою для вивчення регіональних флор, особливо таксонів таксономічно важливих родів Rosa, Crataegus та Rubus. Ці дослідження стосуються різних регіонів Польщі та інших країн, зокрема, територій Національного парку «Низькі Татри» у Словаччині, Розтоцького біосферного заповідника, природного заповідника «Медобори» та Національного природного парку «Подільські товтри» [23] в Україні.

Ключові слова: флористичні дослідження, гербарні колекції, Ойцовський національний парк, Польща 